\title{
ELECTRONIC COMMUNICATION IN THE WORKPLACE: BOON OR BANE?
}

DOI:

10.1108/JOEPP-05-2017-0046

\section{Document Version}

Accepted author manuscript

Link to publication record in Manchester Research Explorer

\section{Citation for published version (APA):}

Tarafdar, M., \& Cooper, C. L. (2018). ELECTRONIC COMMUNICATION IN THE WORKPLACE: BOON OR BANE? Journal of Organizational Effectiveness: People and Performance, 5(1), 98-106.

https://doi.org/10.1108/JOEPP-05-2017-0046

\section{Published in:}

Journal of Organizational Effectiveness: People and Performance

\section{Citing this paper}

Please note that where the full-text provided on Manchester Research Explorer is the Author Accepted Manuscript or Proof version this may differ from the final Published version. If citing, it is advised that you check and use the publisher's definitive version.

\section{General rights}

Copyright and moral rights for the publications made accessible in the Research Explorer are retained by the authors and/or other copyright owners and it is a condition of accessing publications that users recognise and abide by the legal requirements associated with these rights.

\section{Takedown policy}

If you believe that this document breaches copyright please refer to the University of Manchester's Takedown Procedures [http://man.ac.uk/04Y6Bo] or contact uml.scholarlycommunications@manchester.ac.uk providing relevant details, so we can investigate your claim.

\section{OPEN ACCESS}




\title{
ELECTRONIC COMMUNICATION IN THE WORKPLACE: BOON OR BANE?
}

\author{
$\underline{\text { Jean-Francois Stich }}$ \\ ICN Business School, CEREFIGE, Nancy, FR \\ Monideepa Tarafdar \\ Lancaster University Management School, Lancaster University, Lancaster, UK \\ Cary L. Cooper \\ Alliance Manchester Business School, University of Manchester, Manchester, UK
}

Purpose - The purpose of this paper is to review technostress related challenges arising out of workplace communication, for employees and organizations, and to provide suggestions for taking these challenges on.

Design/methodology/approach - The paper presents an overview of current research and practice in the area of technostress related challenges workplace communication.

Findings - Employees face technostress challenges relating to workplace communication in the form of technology overload, interruptions and work-home interferences. Organizations have to strike a balance between giving employees the technology they want and protecting them from these

Practical implications - The paper gives practitioners an accessible overview of current research and practice in the area of technostress from workplace communication such as email. A number of practical interventions are reviewed and commented on, which could help employees tackle such challenges.

Originality/value - Although this paper reviews state-of-the-art research, it is written in an accessible and practitioner-oriented style, which should be found valuable by readers with limited time but urgency to deal with technostress challenges arising out of workplace communication.

Keywords: Information and Communication Technology (ICT), Workplace communication, Email, Stress, Technostress.

Acknowledgements: An earlier draft of this paper was presented to the National Forum for Health and Wellbeing at Work in London, and the authors appreciate the feedback received. 


\section{INTRODUCTION}

The workplace use of Information and Communication Technology (ICT) is pervasive, and growing (Eurofound and the International Labour Office, 2017). Being able to use ICT for workplace related tasks, anytime and anywhere, can certainly have benefits in terms of efficiency, flexibility and productivity (Mano and Mesch, 2010). However, it can also give rise to detrimental side-effects such as 'round-the-clock-alwayson' tethering to the workplace, and leaving employees 'techno-stressed' or even burned out (Barber and Santuzzi, 2015). ICT is thus a double-edged sword both for employees and employers (Stich et al., 2015). Despite ICT and in particular the negative effects of emails, employees often embrace these technologies in the workplace, just as they do in their private lives (Matusik and Mickel, 2011). Practitioners are left with no choice but to ride the ICT bandwagon, wondering nevertheless how to ease the journey. This position paper intends to provide them with state-of-the-art evidence on the effects of electronic communications in the workplace, along with practical and actionable suggestions for embracing ICT challenges in a way that do not leave any employee aside.

In this article, we first describe the dark side of ICT use in the workplace, presenting key research on technology overload and interruptions, on ICT-incurred work-home interferences, and on counterproductive ICT use (i.e., cyberdeviancy). In doing so, we establish the human cost of stress created by ICT (technostress; Tarafdar et al., 2007). We then discuss the cost and importance of such technostress for organizations. As this article is mainly written for a professional audience with urgency to deal with ICT-related problems (e.g., emails), we provide them with extensive suggestions to take these challenges on, based on both key research and our own opinions.

\section{WORKPLACE COMMUNICATION RELATED TECHNOSTRESS CHALLENGES FOR EMPLOYEES}

\subsection{Technology overload}

Although ICT allow for fast transmission of business critical information (Sumecki et al., 2011), it also allows for mass transmission of not-so-critical, sometimes even irrelevant, messages. Using ICT is a time-consuming activity that often forces employees to do things they would not do otherwise (Tarafdar et al., 2007). For instance, most employees cannot bear their email inbox clogging, and ultimately end up using their office hours to "spring-clean" it (Kalman and Ravid, 2015; Whittaker and Sidner, 1996). Research has shown that having to deal with ICT has significantly lengthened people's workdays (Barley et al., 2011). A study found that employees of a large company spent on an average 29 minutes reading email each day, let alone answering them (Jackson et al., 2006). Employees feel that the increasing volume of ICT related communication they are required to handle, not only makes them overloaded technologically, but it also leads to increased 'work' overload (Barley et al., 2011; Gupta et al., 2013). Technology overload has been thus defined as the individuals' perceptions that their communication demands, such as that from email, are out of control and exceeding their coping abilities (Dabbish and Kraut, 2006). These sorts of feelings - of technology overload and the associated work overload are associated with increased risks of burnout, sleep disorders and stress (Barber and Santuzzi, 2015; Mano and Mesch, 2010). Further, although on the face of it, the technology we use feels like it is getting simpler, many applications and devices have complex 'user interfaces' that can take a long time to master, which leads to further work unrelated to their primary tasks and objectives (Tarafdar et al., 2015). To aggravate this situation, short technology life cycles and pressure from vendors means that employees often find themselves continuously dealing with new screens, functionalities and interfaces, often without adequate support. 
This further increases their psychological overload from doing IT-related work (Tarafdar et al., 2015).

\subsection{Interruptions, Divided attention and Multi-tasking}

This never-ending flow of communication results in more frequent interruptions, as employees are compelled to react to their ICT notifications (Stich et al., 2015). Although email can be read anytime, employees tend to react to their incoming email in under one minute 44 seconds on average, and to the majority of it in under six seconds (Jackson et al., 2001). In addition, it is common to see most people looking at their screens in the middle of important meetings and events (Usborne, 2016). Although some interruptions are actually providing timely and needed information that can benefit productivity (Mano and Mesch, 2010), most are just disrupting the task at hand (Jackson et al., 2001). Indeed, employees can take up to fifteen minutes to recover from such interruptions and re-engage in the primary task afterwards (Jackson et al., 2001). Increasingly we find that employees' "attention" is being parcelled among many different tasks at the same time. While multitasking is not necessarily bad for productivity (Li et al., 2011), constant flitting back and forth among different devices and different tasks is time consuming, and results in less sustained attention to one specific task (Addas and Pinsonneault, 2015). It has further been estimated that employees can lose up to 28 minutes of their workday to such interruptions (Gupta and Sharda, 2008). The time and energy lost dealing with such interruptions has adverse consequences for productivity (Addas and Pinsonneault, 2015), and even for physical and mental health (Barber and Santuzzi, 2015).

\subsection{Work-home Interference}

Employees facing increasing technology overload and "around-the-clock" interruptions are tempted to keep on top of their communication and work tasks by using work-related ICT such as tablets, laptops and smartphones at home (Stich et al., 2015).
Indeed, many people prefer doing that because it affords them flexibility, and allows them to integrate their home and work activities (Park et al., 2011). Some - the "Crackberries" (Mazmanian et al., 2005) even become addicted to checking their devices anytime, anywhere, for work-related communication (Weinstein and Lejoyeux, 2010). However, that also means they end up working longer hours, interfering with their personal/family time (Derks et al., 2015). Techno-invasion has been thus been defined as the perception that ICT has invaded one's personal life, and is an important dimension of technostress (Tarafdar et al., 2007). BBC News recently reported that $90 \%$ of UK managers work outside contracted hours using ICT, accounting for an extra day of unpaid overtime per week (BBC News, 2014). The 2017 Eurofound and the International Labour Office (2017) report on "working anytime, anywhere" similarly reports that, in most countries, employees who access ICT outside contracted hours, work longer unsocial hours. Such constant availability allowed by ICT has been associated with increased work-life conflict and job burnout (Derks et al., 2015; Hughes et al., 2017; Stich et al., 2015), even though some victims paradoxically continue to crave for remaining constantly available through ICT (Matusik and Mickel, 2011). The paradox can go as far as employees suing their companies for making them addicted to ICT (Kakabadse et al., 2007). For the others who would rather not integrate their home and work lives (Derks et al., 2016), refusing to bring ICT home is a difficult choice to make. In a recent study of employees, $73 \%$ respondents worried that not being connected to their workplace through their email or other electronic means would place them at a disadvantage at work (Tarafdar et al., 2015).

\subsection{Cyberdeviancy}

Employees are more easily overloaded and interrupted with ICT than in person (Van Solingen et al., 1998), and are also more likely to have their home lives invaded by ICT than by colleagues knocking on their doors. Research shows that employees are also more easily bullied, insulted and 
misinterpreted through ICT than in face-toface (Baruch, 2005; Ford, 2013; Friedman and Currall, 2003; Privitera and Campbell, 2009). Harassment can now extend beyond workplaces and office hours (Baruch, 2005), and cyberbullying has been found to be even more damaging to people's lives than traditional bullying (Ford, 2013). Conflicts are also more likely to escalate through most ICT media due to the difficulty of interpreting messages that are not supplemented by voice and eye contact (Byron, 2008; Friedman and Currall, 2003). Hidden behind computers, employees do not always realize the impacts their messages will have on recipients (Friedman and Currall, 2003), resulting in generally poorer workplace communication (Stich et al., 2015). Employees may also think ICT hide them from their employers' surveillance, resulting in counterproductive work behaviours such as spending office hours on social media (Cyberslacking or cyberloafing; Schmidt and O'Connor, 2015) or on illegal content (e.g., cyberpornography or piracy), or seizing confidential data for their own benefit (data theft). These activities, referred to as "cyberdeviancy" (Weatherbee, 2010), incur significant human and financial costs for organizations (Weatherbee, 2010).

\section{WORKPLACE COMMUNICATION RELATED TECHNOSTRESS - CHALLENGES FOR ORGANIZATIONS}

\subsection{Between a rock and a hard place - Giving employees the technology they want}

The aforementioned effects of ICT use are difficult to mitigate given the diverse ways they impact individuals. Knowing the risks of bringing work related ICT home does not prevent employees from embracing constant availability. They often feel an increased sense of job satisfaction, professionalism, productivity, autonomy, control and empowerment (Diaz et al., 2012), even justifying their inability to disconnect from work communication as a matter of free choice (Cavazotte et al., 2014). Should organizations go along with this and encourage employees to access work related communication outside contracted hours? Organizations have the difficult task to both provide employees with the technology they want, while at the same time steer them away from "self-inflicted work-life conflict" (Wright et al., 2014, p. 524), or "self-imposed escalation of work-related connectivity" (Cavazotte et al., 2014, p. 82). In addition to protecting their employees, they must also protect themselves from the costs incurred by ICT misuse and cyberdeviancy by reinforcing their legal and technological arsenal (E.g., electronic monitoring; Smith and Tabak, 2009). This challenge is made even more difficult with the never-ending introduction of new technologies in the consumer market, which at some point become desirable to employees (Matusik and Mickel, 2011). Organizations may be tempted "to advance the technology per se rather than to consider its impact on individual workers" (O'Driscoll et al., 2009, p. 126). Although these new technologies are desired and asked for by employees, "we must be vigilant in assessing the human costs that are incurred when these advances are adopted in the workplace" (Mark et al., 2012, p. 563). And even then, organizations that refuse to adopt such advances cannot guarantee that their employees will not themselves adopt them, thereby circumventing their IT departments and surveillance policies (BYOD; Crossler et al., 2014)...

\subsection{Dealing with varying ability to use ICT}

Although ICT can provide a platform for organizations to actually address the communication needs and expectations of employees, it also requires successful training and technology habituation of people who may be technophobic (Townsend et al., 1998). Not everyone likes technology or can use it well or effectively. For example employees who lack the ability to manage and sort their email, experience greater email overload that those who do not (Soucek and Moser, 2010). At the same time those who cannot send concise and clear emails increase their colleagues' email overload (Jackson and Lichtenstein, 2011). They also make conflicts and feelings of harassment more likely to 
occur, given the difficulty of writing unambiguous and polite messages (Friedman and Currall, 2003). ICT enabled work communication is social and interactive. Such problems are thus often matters of "collective drowning" in the email deluge (Mazmanian et al., 2005; Thomas and King, 2006)! A major organisational challenge is therefore to improve the ability of all employees to use ICT effectively, in order to limit these sorts of detrimental outcomes.

\section{WORKPLACE COMMUNICATION RELATED TECHNOSTRESS - TAKING IT ON}

\subsection{Specify clear ICT use guidelines}

Organizations can design interventions aiming at mitigating these negative outcomes. To prevent work-life imbalance, some organizations have decided to block access to emails outside contracted hours in order to force employees to take sufficient time off work. For example, in Germany, Volkswagen stopped routing emails to some employees on shift (BBC News, 2012). In France, Atos decided in 2010 to progressively replace emails with other, supposedly more efficient, media such as enterprise social networks. In $2014,40,000$ of their 80,000 employees, sent less than 20 emails per week, compared to an average of 100 in 2010 (Filippone, 2014). Their ambitious objective has served as a catalyst for imagining innovative ways to reduce technostress (Pillet and Carillo, 2016). It has been further suggested that "the cost of email use can be optimised by reducing the volume of irrelevant and untargeted email and by reducing the frequency with which an email application checks for new email" (Jackson and Lichtenstein, 2011, p. 20). If organizations do not want to bear the costs of email use, a paper went as far as to suggest, rather ironically, that email senders could be "charged according to the number of recipients" (Hiltz and Turoff, 1985, p. 688). Such measures, although draconian, do serve to send clear signals as to what is organizationally acceptable or not, with respect to use of ICT, thereby defining and sharing norms of proper ICT use (Matusik and Mickel, 2011). This would, therefore, be similar to norms enforced and shared by cyberbullying policies (West et al., 2014) or general ICT use guidelines, defining the boundaries of cyberdeviancy and deterring employees from engaging in such counterproductive behaviours.

\subsection{Develop more careful "one-size-fits-all" interventions}

However, "strategies aimed at simply reducing email volume and changing individual behaviours may not be enough" (Sumecki et al., 2011, p. 413). Such unilateral interventions are difficult and risky to design, given that some employees may also experience high levels of stress and inadequacy when they lack the ICT and constant availability they need or desire (Stich et al., 2017). To the question "why do some individuals thrive in this environment whereas others suffer?" (Macik-Frey et al., 2007, p. 823), research has found that employees thrive when they can use the technology they need and want, and suffer when they cannot (Stich et al., 2017). Among less risky "one-size-fits-all" interventions is the elaboration of organizational guidelines giving advice and guidance to employees about mitigating their technostress (Wright et al., 2014). In France, large organizations are now forced by law, since January $1^{\text {st }} 2017$, to create such guidelines in which they describe how they intend to support their employees' "right to disconnect" and disengage from work while at home.

Such guidelines may contain promises to train employees on how to use emails and ICT and protect themselves against technostress. They may also contain guidance for dealing with cyberbullying (West et al., 2014). Email training for instance, has been found to reduce trainees' levels of email overload and their colleagues' levels of email overload (Soucek and Moser, 2010). Email training interventions can include a demonstration of email features (sorting, filtering), examples of poorly-written email, simulation exercises and collaborative writing of "proper email use" guidelines (2010). Further workshop training can be provided on virtual civility, respect and 
engagement at work (CREW; Giumetti et al., 2013) in order to reduce cyberdeviancy in the workplace.

\subsection{Help individuals be mindful of their own use of ICT}

Besides these organizational innovations that can be applied to all employees, interventions and guidelines can also be applied individually to each employee. Internal surveys could audit employees' levels of technostress and attitudes towards ICT, and their results could serve as a basis for collective discussions in the company, through peer support groups. Technostress (Tarafdar et al., 2015), stress (Cartwright and Cooper, 2002) and cyberbullying (Farley et al., 2016) instruments reported in recent studies could be the basis of discussions among employees regarding their preferences for and reactions to use of ICT.

\subsection{Help individuals be mindful of their colleague's use of ICT}

Employees with managerial responsibilities have a special role to play in reducing everyone's technostress. Managers sending email to their subordinates outside their contracted hours create even stronger response expectations, and implicitly encourage a culture of constant availability (Derks et al., 2015).

Managers are, therefore, the ones who both suffer the most from technostress, and have the most impact on others' technostress (Waller and Ragsdell, 2012)! They should, therefore, be at the centre of organisational interventions such as workplace guidelines on email use. Organizations should also encourage employees to understand and empathise with the email and ICT use preferences of their colleagues. This could include, understanding communication habits of immediate colleagues, for example, what communication medium they prefer, and how they prefer to use it (Stich et al., 2017).

In conclusion, the pervasiveness of these problems we describe, demands that senior executives and HR managers come together to frame and implement solutions (Tarafdar et al., 2015). Senior leadership should make mindful use of emails and ICT an organizational priority and commit to provide support and resources for tackling these problems. Human Resource managers should monitor employee sentiments and problems with regard to the stressful demands they face from emails, social media and other communication software. They should provide training and resources for employees to maintain their work life balance and create repositories for support resources. IT managers should provide technical support on issues such as how to switch off email alerts and how to better manage their email.

As John Ruskin, the British social reformer wrote, at the beginning of the Industrial Revolution in 1851:

"In order that people may be happy in their work, these three things are needed: they must be fit for it; they must not do too much of it; and they must have a sense of success in it."

This is the challenge of HR in respect of new technology in the $21^{\text {st }}$ Century. 


\section{REFERENCES}

Addas, S. and Pinsonneault, A. (2015), "The many faces of information technology interruptions: a taxonomy and preliminary investigation of their performance effects", Information Systems Journal, Vol. 25 No. 3, pp. 231-273.

Barber, L.K. and Santuzzi, A.M. (2015), "Please Respond ASAP: Workplace Telepressure and Employee Recovery", Journal of Occupational Health Psychology, Vol. 20 No. 2, pp. 172-189.

Barley, S.R., Meyerson, D.E. and Grodal, S. (2011), "E-mail as a Source and Symbol of Stress", Organization Science, Vol. 22 No. 4, pp. 887906.

Baruch, Y. (2005), "Bullying on the net: adverse behavior on e-mail and its impact", Information \& Management, Vol. 42 No. 2, pp. 361-371.

BBC News. (2012), "Volkswagen turns off Blackberry email after work hours", 8 March, available at: $\quad$ http://www.bbc.com/news/technology16314901 (accessed 10 May 2017).

BBC News. (2014), "Managers 'work extra day per week in unpaid overtime"”, BBC News, 9 July, available

at: http://www.bbc.com/news/business-28220312 (accessed 8 September 2015).

Byron, K. (2008), “Carrying Too Heavy a Load? The Communication and Miscommunication of Emotion by Email", Academy of Management Review, Vol. 33 No. 2, pp. 309-327.

Cartwright, S. and Cooper, C.L. (2002), "ASSET: Management guide", Manchester, UK: RobertsonCooper Ltd.

Cavazotte, F., Heloisa Lemos, A. and Villadsen, K. (2014), "Corporate smart phones: professionals' conscious engagement in escalating work connectivity", New Technology, Work and Employment, Vol. 29 No. 1, pp. 72-87.

Crossler, R.E., Long, J.H., Loraas, T.M. and Trinkle, B.S. (2014), "Understanding Compliance with Bring Your Own Device Policies Utilizing Protection Motivation Theory: Bridging the Intention-Behavior Gap", Journal of Information Systems, Vol. 28 No. 1, pp. 209226.

Dabbish, L.A. and Kraut, R.E. (2006), "Email overload at work: an analysis of factors associated with email strain", Proceedings of the 2006 20th Anniversary Conference on Computer Supported Cooperative Work, ACM, Banff, Alberta, Canada, pp. 431-440.
Derks, D., Bakker, A.B., Peters, P. and Wingerden, P. van. (2016), "Work-related smartphone use, work-family conflict and family role performance: The role of segmentation preference", Human Relations, Vol. 69 No. 5, pp. $1045-1068$.

Derks, D., van Duin, D., Tims, M. and Bakker, A.B. (2015), "Smartphone use and work-home interference: The moderating role of social norms and employee work engagement", Journal of Occupational and Organizational Psychology, Vol. 88 No. 1, pp. 155-177.

Diaz, I., Chiaburu, D.S., Zimmerman, R.D. and Boswell, W.R. (2012), "Communication technology: Pros and cons of constant connection to work", Journal of Vocational Behavior, Vol. 80 No. 2, pp. 500-508.

Eurofound and the International Labour Office. (2017), Working Anytime, Anywhere: The Effects on the World of Work, Publications Office of the European Union, Luxembourg, and the International Labour Office, Geneva.

Farley, S., Coyne, I., Axtell, C. and Sprigg, C. (2016), "Design, development and validation of a workplace cyberbullying measure, the WCM", Work \& Stress, Vol. 30 No. 4, pp. 293-317.

Filippone, D. (2014), "Zéro mail chez Atos : la SSII at-elle gagné son pari?", Journal Du Net, 15 April, available at: http://www.journaldunet.com/solutions/reseau -social-d-entreprise/atos-strategie-zeromail.shtml (accessed 10 May 2017).

Ford, D.P. (2013), "Virtual harassment: media characteristics' role in psychological health", Journal of Managerial Psychology, Vol. 28 No. 4, pp. 408-428.

Friedman, R.A. and Currall, S.C. (2003), "Conflict escalation: Dispute exacerbating elements of e-mail communication", Human Relations, Vol. 56 No. 11, pp. 1325-1347.

Giumetti, G.W., Hatfield, A.L., Scisco, J.L., Schroeder, A.N., Muth, E.R. and Kowalski, R.M. (2013), "What a rude e-mail! Examining the differential effects of incivility versus support on mood, energy, engagement, and performance in an online context", Journal of Occupational Health Psychology, Vol. 18 No. 3, pp. 297-309.

Gupta, A., Li, H. and Sharda, R. (2013), "Should I send this message? Understanding the impact of interruptions, social hierarchy and perceived task complexity on user performance and perceived workload", Decision Support Systems, Vol. 55 No. 1, pp. 135-145. 
Gupta, A. and Sharda, R. (2008), "SIMONE: A Simulator for Interruptions and Message Overload in Network Environments", International Journal of Simulation and Process Modelling, Vol. 4 No. 3-4, pp. 237247.

Hiltz, S.R. and Turoff, M. (1985), "Structuring Computer-mediated Communication Systems to Avoid Information Overload", Communications of the ACM, Vol. 28 No. 7, pp. 680-689.

Hughes, R., Kinder, A. and Cooper, C.L. (2017), The Crisis Book: Overcoming and Surviving WorkLife Challenges, Lid Publishing, London.

Jackson, T.W., Burgess, A. and Edwards, J. (2006), “A simple approach to improving email communication", Communications of the ACM, Vol. 49 No. 6, pp. 107-109.

Jackson, T.W., Dawson, R. and Wilson, D. (2001), "The cost of email interruption", Journal of Systems and Information Technology, Vol. 5 No. 1, pp. 81-92.

Jackson, T.W. and Lichtenstein, S. (2011), “Optimising e-mail communication: the impact of seminarand computer-based training", International Journal of Internet and Enterprise Management, Vol. 7 No. 2, pp. 197-216.

Kakabadse, N., Porter, G. and Vance, D. (2007), "Addicted to technology", Business Strategy Review, Vol. 18 No. 4, pp. 81-85.

Kalman, Y.M. and Ravid, G. (2015), "Filing, piling, and everything in between: The dynamics of E-mail inbox management", Journal of the Association for Information Science and Technology, Vol. 66 No. 12, pp. 2540-2552.

Li, H., Gupta, A., Luo, X. and Warkentin, M. (2011), "Exploring the impact of instant messaging on subjective task complexity and user satisfaction", European Journal of Information Systems, Vol. 20 No. 2, pp. 139155.

Macik-Frey, M., Quick, J.C. and Nelson, D.L. (2007), "Advances in Occupational Health: From a Stressful Beginning to a Positive Future", Journal of Management, Vol. 33 No. 6, pp. 809-840.

Mano, R.S. and Mesch, G.S. (2010), "E-mail characteristics, work performance and distress", Computers in Human Behavior, Vol. 26 No. 1, pp. 61-69.

Mark, G., Voida, S. and Cardello, A. (2012), “A pace not dictated by electrons: an empirical study of work without email", Proceedings of the SIGCHI Conference on Human Factors in Computing Systems, ACM, pp. 555-564.
Matusik, S.F. and Mickel, A.E. (2011), "Embracing or embattled by converged mobile devices? Users' experiences with a contemporary connectivity technology", Human Relations, Vol. 64 No. 8, pp. 1001-1030.

Mazmanian, M., Orlikowski, W.J. and Yates, J. (2005), "Crackberries: The social implications of ubiquitous wireless e-mail devices", in Sørensen, C., Yoo, Y., Lyytinen, K. and DeGross, J. (Eds.), Designing Ubiquitous Information Environments: Socio-Technical Issues and Challenges, Springer, New York, pp. 337-343.

O’Driscoll, M.P., Biron, C. and Cooper, C.L. (2009), "Work-related technological change and psychological well-being", in AmichaiHamburger, Y. (Ed.), Technology and Psychological Well-Being, Cambridge University Press.

Park, Y., Fritz, C. and Jex, S.M. (2011), "Relationships between work-home segmentation and psychological detachment from work: The role of communication technology use at home.", Journal of Occupational Health Psychology, Vol. 16 No. 4, pp. 457-467.

Pillet, J.-C. and Carillo, K.D.A. (2016), "Email-free collaboration: An exploratory study on the formation of new work habits among knowledge workers", International Journal of Information Management, Vol. 36 No. 1, pp. 113-125.

Privitera, C. and Campbell, M.A. (2009), "Cyberbullying: The New Face of Workplace Bullying?", CyberPsychology \& Behavior, Vol. 12 No. 4, pp. 395-400.

Schmidt, G.B. and O'Connor, K.W. (2015), "Fired for Facebook: Using NLRB guidance to craft appropriate social media policies", Business Horizons, Vol. 58 No. 5, pp. 571-579.

Smith, W.P. and Tabak, F. (2009), "Monitoring Employee E-mails: Is There Any Room for Privacy?", Academy of Management Perspectives, Vol. 23 No. 4, pp. 33-48.

Soucek, R. and Moser, K. (2010), "Coping with information overload in email communication: Evaluation of a training intervention", Computers in Human Behavior, Vol. 26 No. 6, pp. 1458-1466.

Stich, J.-F., Farley, S., Cooper, C. and Tarafdar, M. (2015), "Information and communication technology demands: outcomes and interventions", Journal of Organizational Effectiveness: People and Performance, Vol. 2 No. 4, pp. 327-345. 
Stich, J.-F., Tarafdar, M., Cooper, C.L. and Stacey, P. (2017), "Workplace stress from actual and desired computer-mediated communication use: a multi-method study", New Technology, Work and Employment, Vol. 32 No. 1, pp. 84100 .

Sumecki, D., Chipulu, M. and Ojiako, U. (2011), "Email overload: Exploring the moderating role of the perception of email as a 'business critical' tool", International Journal of Information Management, Vol. 31 No. 5, pp. 407-414.

Tarafdar, M., D’Arcy, J., Turel, O. and Gupta, A. (2015), "The Dark Side of Information Technology", Sloan Management Review, Vol. 56 No. 2, pp. 60-71.

Tarafdar, M., Qiang Tu, Ragu-Nathan, B.S. and RaguNathan, T.S. (2007), "The Impact of Technostress on Role Stress and Productivity", Journal of Management Information Systems, Vol. 24 No. 1, pp. 301328.

Thomas, G.F. and King, C.L. (2006), "Reconceptualizing E-Mail Overload", Journal of Business and Technical Communication, Vol. 20 No. 3, pp. 252-287.

Townsend, A.M., DeMarie, S.M. and Hendrickson, A.R. (1998), "Virtual teams: Technology and the workplace of the future", Academy of Management Executive, Vol. 12 No. 3, pp. 1729.

Usborne, S. (2016), "What were all those MPs doing on their phones?", The Guardian, 25 November, available at: https://www.theguardian.com/technology/201 6/nov/25/what-were-labour-mps-doing-ontheir-mobile-phones-in-parliament (accessed 10 May 2017).

Van Solingen, R., Berghout, E. and Van Latum, F. (1998), "Interrupts: just a minute never is", IEEE Software, Vol. 15 No. 5, pp. 97-103.

Waller, A.D. and Ragsdell, G. (2012), "The impact of e-mail on work-life balance", Aslib Proceedings, Vol. 64 No. 2, pp. 154-177.

Weatherbee, T.G. (2010), "Counterproductive use of technology at work: Information \& communications technologies and cyberdeviancy", Human Resource Management Review, Vol. 20 No. 1, pp. 3544.

Weinstein, A. and Lejoyeux, M. (2010), "Internet addiction or excessive internet use", The American Journal of Drug and Alcohol Abuse, Vol. 36 No. 5, pp. 277-283.
West, B., Foster, M., Levin, A., Edmison, J. and Robibero, D. (2014), "Cyberbullying at work: In search of effective guidance", Laws, Vol. 3 No. 3, pp. 598-617.

Whittaker, S. and Sidner, C. (1996), "Email Overload: Exploring Personal Information Management of Email", Proceedings of the SIGCHI Conference on Human Factors in Computing Systems, ACM, New York, NY, USA, pp. 276-283.

Wright, K.B., Abendschein, B., Wombacher, K., O’Connor, M., Hoffman, M., Dempsey, M., Krull, C., et al. (2014), "Work-Related Communication Technology Use Outside of Regular Work Hours and Work Life Conflict The Influence of Communication Technologies on Perceived Work Life Conflict, Burnout, Job Satisfaction, and Turnover Intentions", Management Communication Quarterly, Vol. 28 No. 4, pp. 507-530. 